UDC 338.45:664.95(477)

DOI: $10.15673 /$ fie.v13i3.2132

\author{
Samofatova V. \\ Doctor of Economics, Professor \\ E-mail: vica samofatova@meta.ua \\ ORCID ID: 0000-0002-9058-4382 \\ Bova T. \\ Undergraduate \\ Department of Industrial Economics \\ Odessa National Academy of Food Technologies \\ Street Kanatna, 112, Odesa, Ukraine, 65039 \\ E-mail: tatiana.bova00@gmail.com \\ ORCID: 0000-0001-9713-3624
}

\title{
PROBLEMS AND PROSPECTS OF DEVELOPMENT OF CONFECTIONERY INDUSTRY ENTERPRISES IN UKRAINE
}

The article is devoted to the analysis of the modern confectionery market of Ukraine. This article examines the state of the confectionery industry and highlights the main trends and problems in the development of the confectionery market in Ukraine. It identifies the main factors influencing the increase of competitiveness of confectionery enterprises and the development of the confectionery industry in Ukraine and highlights the problems related to sourcing domestic and imported raw materials for production. It contains a list of the largest exporting countries of cocoa, cocoa beans and cocoa products to Ukraine. The articles considers opportunities and problems of export of Ukrainian confectionery products and contains a list of the largest importing countries of Ukrainian confectionery products. The analysis was made of the dynamics of the volume of exported production and the total volume of sales of confectionery products over several years. The main reasons for the decline in confectionery exports have been identified. The ways to improve the efficiency of domestic confectionery sales have been indicated. The article determines that to strengthen their market positions, the enterprises need to monitor the quality of their products and equipment, ensure the relevance of marketing activities to increase sales, improve the existing product range and develop new, exclusive products that could take a free market niche, and also look for ways to export, diversify or find new ways to market products sale in Ukraine.

Key words: Confectionery industry, efficiency, competitiveness, confectionery markets, sales markets, export, import.

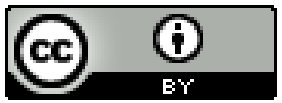

This work is licensed under a Creative Commons Attribution 4.0 International License http://creativecommons.org/licenses/by/4.0/
Statement of the problem and its connection with important scientific and practical tasks. Confectionery products are an important component of modern human nutrition. Of course, the reason for the high demand for these products is not only their variety and richness of taste. The high sugar content of certain confectionery products gives them a high energy value, and products containing cocoa have tonic properties. In addition, a healthy food market is beginning to take shape in Ukraine, with a certain share of healthier confectionery products made with the addition of natural fruit and vegetable juices and purees, soy products, wheat germ, natural food additives, etc[1].

The confectionery industry also plays a big role in shaping Ukrainian economy. Confectionery products are in demand among Ukrainians, production requires the use of domestic raw materials and sales in retail chains. This helps to support the development of other areas of Ukrainian economic activity, and, in addition, enterprise taxes are an important source of revenue for the state budget. However, the constant development of the industry and the emergence of an increasing number of enterprises have led to fierce competition in the confectionery market.

The analysis of the latest publications on the problem. There are many academics involved in investigating the state of the confectionery market in Ukraine, identifying its trends and problems, such as V.Volkov [1], A. Zagrychanshka, V. Goluk [2], A. Tichinska, M. Naumova [10], M.Shashina[13], M. Ribak [14], K.Demyanenko [15], O. Tobolin [16]. However, the rapid changes in the market and the constant development of the industry require further study and research into new emerging issues.

Forming of the aims of the research. The purpose of the study is to analyse the current state of the confectionery market in Ukraine and to identify current problems and further prospects of its development.

Giving an account of the main results and their substantiation. The current state of the market of 
confectionery in Ukraine is characterized by the instability of the external environment of the enterprises, rapid changes in consumer demand, fierce competition between a large number of companies of different categories and forms of ownership, increasing consumer demands for products. Although confectionery is not a basic necessity, the demand for it remains relatively constant: according to the State Statistics Service of Ukraine, spending on confectionery will account for $6.8 \%$ of Ukrainian households' total food expenses in 2019, $6.2 \%$ in 2020, and $6.3 \%$ in the first quarter of 2021 [3]. This is one of the reasons why more and more confectioneries with a similar or analogous assortment of products appear every year, which makes potential customers pay particular attention to the price difference, the breadth of the range and the quality of the competitors' products. Looking at trends in the Ukrainian confectionery market, it can be said that today it is at the stage of completion of its formation and, without a doubt, in a state of fierce competitive confrontation. The research shows that among domestic consumers' preferences, more than $95 \%$ of the market is occupied by products from domestic companies, whose number is steadily increasing every year: for example, 284 new companies focused on confectionery products were registered during 2019, including 280 small and 3 medium-sized ones [4]. To hold their position in the industry reliably, enterprises need to monitor closely all trends in their competitive environment and respond to them in a certain way. Every enterprise needs to be able to properly assess the market situation and choose effective means of competition that, on the one hand, would be adequate to the market situation in Ukraine and its development trends, and, on the other hand, would correspond to the specifics of this enterprise. It should not be forgotten that competition is an important and effective tool for the development of a country's economic system because it is the reason why companies, when competing for leadership, resort to analysing and improving their activities. As a result, this brings them greater market success and the ability to hold onto their position more firmly in the battle for potential consumers.

Among all the factors affecting the competitiveness of enterprises and driving the development of the confectionery industry in Ukraine, it is possible to identify five very closely related key factors.

The first among these, of course, are the raw materials and resources used to make the products. The confectionery industry provides significant demand for domestic agricultural raw materials, as products such as milk, eggs, sugar, flour, honey, nuts, berries and fruits, etc. are often used in the production of sweets. Rising prices for domestic raw materials could have a strong impact on the value of the confectionery industry's finished products. This, in turn, against the background of slow income growth, may lead to a decrease in Ukranians' consumption of some relatively expensive confectionery products, such as cakes and pastries. In addition, seasonal fluctuations in raw material prices and higher production costs could cause Ukrainian producers to lose significant profits and competitive advantages on foreign markets [5, c.18-19].

The availability of domestic raw materials was a prerequisite for the formation and further development of a strong confectionery industry in Ukraine, but nowadays the vast majority of products also use cocoa, cocoa beans and cocoa products - in 2020 imports of cocoa, cocoa beans and cocoa products cost Ukrainian producers almost \$376 million - table 1.

Table 1

The largest exporters of cocoa, cocoa beans and cocoa products to Ukraine in 2020*

\begin{tabular}{|c|c|c|c|}
\hline \multirow{2}{*}{ № } & Exporters & $\begin{array}{c}\text { Value of imported raw materials in } \\
\text { 2020 (USD thousand) }\end{array}$ & Share in Ukraine's imports (\%) \\
\hline \multicolumn{2}{|c|}{ World } & $\mathbf{3 7 5 9 2 5}$ & $\mathbf{1 0 0 , 0 0 \%}$ \\
\hline 1 & Côte d'Ivoire & 68509 & $18,22 \%$ \\
\hline 2 & Poland & 64021 & $17,03 \%$ \\
\hline 3 & Netherlands & 54724 & $14,56 \%$ \\
\hline 4 & Germany & 43230 & $11,50 \%$ \\
\hline 5 & Ghana & 32789 & $8,72 \%$ \\
\hline 6 & Austria & 14064 & $3,74 \%$ \\
\hline 7 & Malaysia & 12936 & $3,44 \%$ \\
\hline 8 & Belgium & 12042 & $3,20 \%$ \\
\hline 9 & Italy & 11004 & $2,93 \%$ \\
\hline 10 & Indonesia & 10196 & $2,71 \%$ \\
\hline 11 & Bulgaria & 8032 & $2,14 \%$ \\
\hline 12 & Turkey & 7556 & $2,01 \%$ \\
\hline 13 & Hungary & 7436 & $1,98 \%$ \\
\hline
\end{tabular}


Continue of Table 1

The largest exporters of cocoa, cocoa beans and cocoa products to Ukraine in 2020 *

\begin{tabular}{|c|c|c|c|}
\hline № & Exporters & $\begin{array}{c}\text { Value of imported raw materials in } \\
\text { 2020 (USD thousand) }\end{array}$ & Share in Ukraine's imports (\%) \\
\hline 14 & Belarus & 5571 & $1,48 \%$ \\
\hline 15 & Spain & 4133 & $1,10 \%$ \\
\hline 16 & Czech Republic & 3789 & $1,01 \%$ \\
\hline
\end{tabular}

*Developed by the authors based on [6]

Cocoa, cocoa beans and cocoa products are imported raw materials and this makes domestic confectioners quite sensitive to currency risks, which can also significantly affect the final cost of production and cause a significant fall in demand.

The second, no less important factor, is the possibility for domestic producers to export their products. Strong domestic competition in the industry forces producers to actively compete for the local market and lower prices for goods. As a result, this causes deterioration of the quality of the products due to the use of cheaper raw materials. Despite generally positive trends in the development of the Ukrainian confectionery market, the share of exports in total sales volume of confectionery

products has been gradually decreasing in recent years (Figure 1). This is due both to significant changes in the global market and deteriorating quality of Ukrainian products to maintain positions in the domestic market, inefficient marketing and sales programmes, exchange rate volatility and high competition from foreign confectioneries.

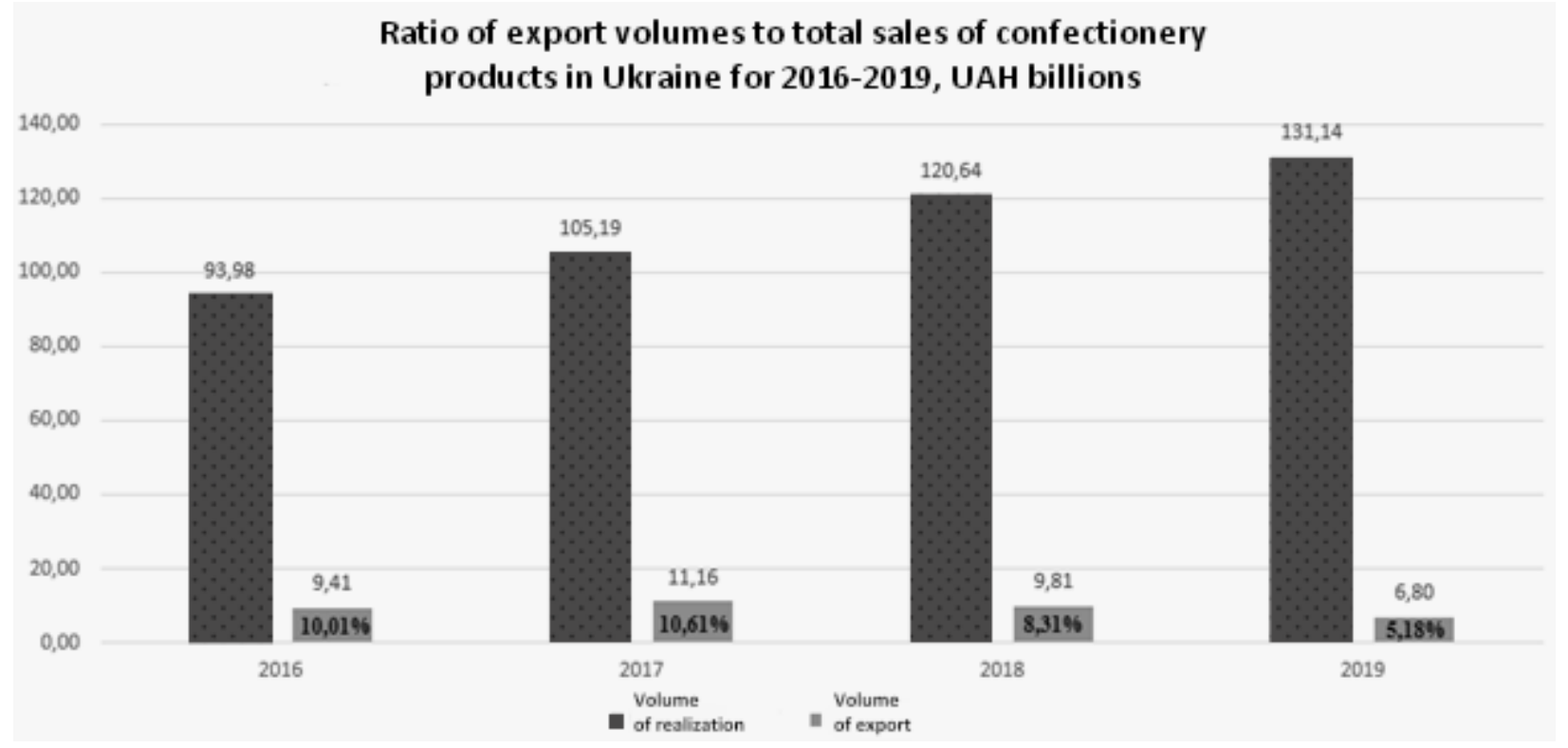

Figure 1. Ratio of export volumes to total sales of confectionery products in Ukraine for 2016-2019* *developed by the authors based on [7]

Nevertheless, among Ukrainian enterprises some are actively taking advantage of opportunities and bringing new confectionery products to foreign markets, encouraging the absence of duties on sweets in the European Union and gradually increase their share of exports. Ukraine's confectionery market is getting stronger, and this can be seen in the positions taken by Ukrainian confectioners in the world's largest confectionery companies ranking - Global Top 100 Candy Companies. In 2020, domestic industry leaders such as "Roshen", "AVK", "Millenium" and "Konti Group" were included in the list of the world's largest producers of sweets - table 2 .

According to the statistics on exports of
Ukrainian confectionery products in 2020 [9], the most exports were to countries such as Poland, Belarus, Romania, Kazakhstan, Turkey, Germany, Azerbaijan, the UK and Indonesia - together they import more than half of Ukraine's confectionery products. It is worth noting that this list has changed significantly in recent years, and in order to increase sales of confectionery products, there are plans to consider exporting Ukrainian confectionery products to countries such as China, India, Ghana and Nigeria [10, c. 125].

The third factor influencing the competitiveness of enterprises and the development of the confectionery industry is the consumer of products. High competition between enterprises, the increase in the number of private 
enterprises with a small assortment and high prices, but higher quality, fresher and more attractive products, the general oversaturation of the confectionery market, the decline in purchasing power of the population as a result of the difficult economic situation in the country caused by the pandemic is forcing consumers to pay more attention to the choice and purchase of confectionery products.

Table 2

Dynamics of places held by Ukrainian confectionery industry leaders in the Global Top 100 Candy Companies 2016-2021*

\begin{tabular}{|l|c|c|c|c|c|c|}
\hline \multirow{2}{*}{ Enterprises } & \multicolumn{5}{|c|}{ Place in the top 100 } \\
\cline { 2 - 7 } & First half of 2021 & 2020 & 2019 & 2018 & 2017 & 2016 \\
\hline Roshen & 29 & 27 & 27 & 25 & 24 & 22 \\
\hline AVK & $\mathrm{x}$ & 65 & $\mathrm{x}$ & 64 & 67 & 62 \\
\hline Millenium & 73 & 74 & $\mathrm{x}$ & $\mathrm{x}$ & $\mathrm{x}$ & $\mathrm{x}$ \\
\hline Konti & 89 & 80 & 44 & 43 & 43 & 38 \\
\hline
\end{tabular}

*Improved by the authors based on [8]

Despite the popularity of confectionery products, the demand for them is spontaneous most often confectionery products become one of the main items of cost saving for Ukrainians. In order to stimulate sales, manufacturers should pay a lot of attention to packaging design, trying to make it as modern and original as possible, corresponding to attractive bright designs of imported goods; marketing activities, primarily advertising via the Internet and creating advertising blogs on popular social networks and, if possible, distributing products not only through retail chains, but also by placing their own outlets in crowded places. As an illustrative example, we can see the ranking of chocolate bar brands in 2020 based on consumer ratings in Figure 2.

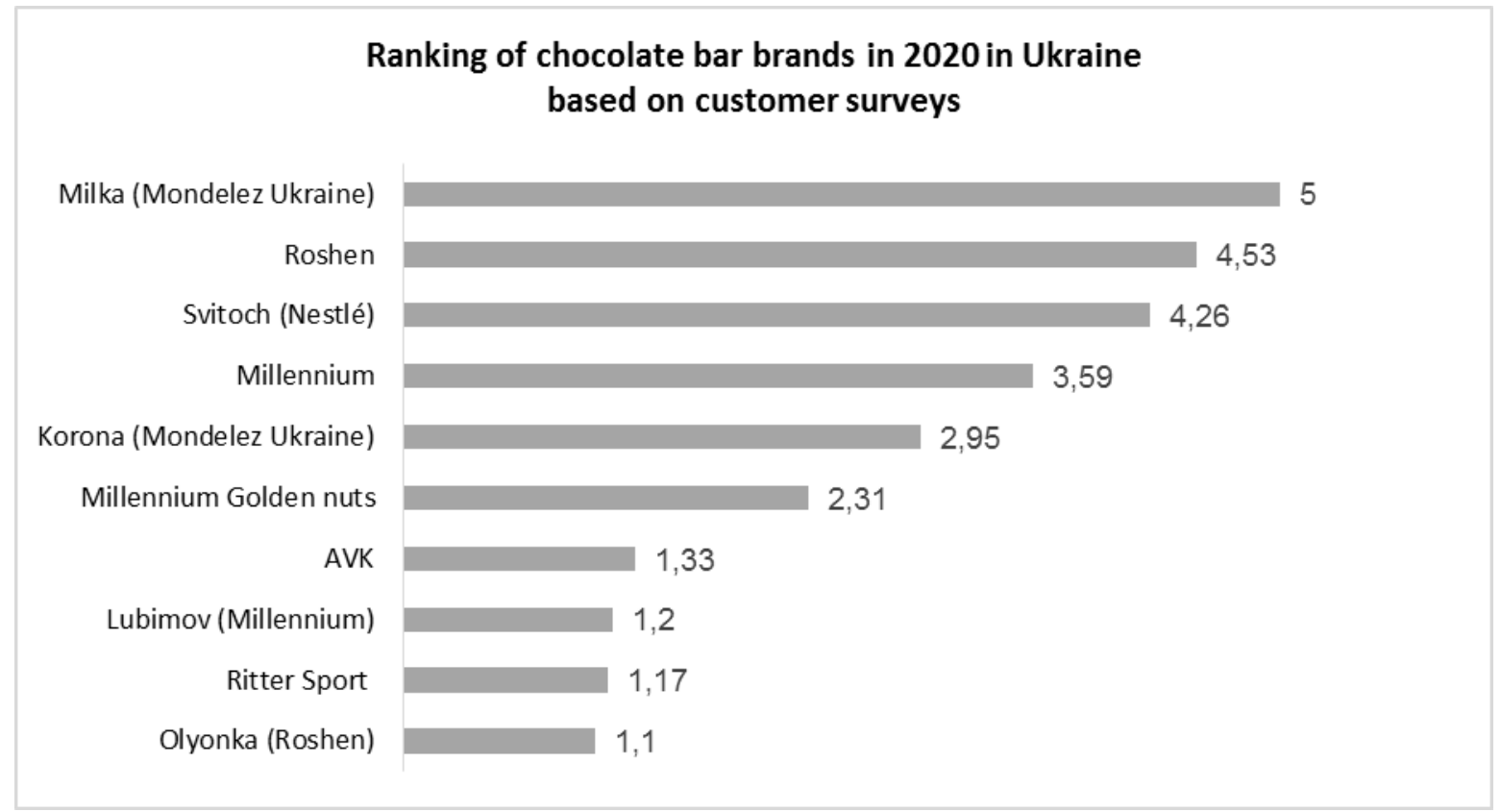

Figure 2. Ranking of chocolate bar brands in 2020 in Ukraine based on customer surveys* *compiled by the authors based on [7]

This brings us to the next, fourth factor - product sales. One of the pressing problems of confectionery sales in Ukraine is the strained relationship that often arises between confectionery businesses and retail chains. Since the amount of retail space is limited and there are not many large retail chains in Ukraine that are able to sell large quantities of confectionery products, retail chains can set their terms for confectioners - including offering producers to sell products on demand and under their own brand, which often results in lower sales revenues than planned. In addition, the payment discipline of retailers is often low, leaving confectioners with no choice but to cooperate with retailers on uncomfortable and dangerous terms of permanent interest-free long-term loans. This is the reason why products from large market-leading confectionery companies and imported goods are often seen on shop shelves [10, c.78]. 
The way out may be to open your chain of shops, to cooperate with small local retailers, or to start exporting of products.

The fifth and final, but very important factor is the marketing policy of companies. Nowadays, proper advertising of a product is one of the most important steps towards its sale. It is the source of information through which the potential consumer learns about the product; it exerts a certain psychological influence on the consumer, convincing him to purchase the product. Unfortunately, many producers of confectionery products neglect marketing activities and don't take care of quality promotion of their products, and this is the reason why they are overshadowed by more successful competitors. It shouldn't be forgotten that a large number of confectionery products are bought as gifts, and the target audience of this kind of products consists mainly of children and young people, who pay special attention to interesting advertising and modern product appearance. This is why manufacturers should not forget about promoting their products on the market - developing a website with information about their products, blogging on social networks, advertising on the Internet and at product outlets, preparing an original stylish product wrapper design that could change during themed holidays, as well as holding promotions and events will help increase the interest of potential customers, attract new audiences and increase revenue from sales of their products.

Conclusions and prospects of the further investigations. Looking at trends in the Ukrainian confectionery market, it can be said that today it is at the stage of completion of its formation and, without a doubt, in a state of fierce competitive confrontation. To hold their position in the industry reliably, enterprises need to monitor closely all trends in their competitive environment and respond to them in a certain way. Enterprises in this industry have a lot of positive features that allow them to develop and expand: the availability of domestic sources of primary raw materials for production, a wide target audience and a large number of potential consumers, the possibility of occupying a new market niche through exporting products to several different countries around the world and ample opportunities to expand production and obtain investment in new projects. At the same time, many challenges prevent the confectionery industry from increasing its growth rate. These include the possible increase in the cost of imported raw materials due to currency appreciation and seasonal increases in the value of domestic raw materials, the deterioration in the country's economic situation and loss of purchasing power of the population due to the pandemic, the need to keep prices down to ensure the competitiveness of products on the market, the limited commercial space and the lack of large retail chains to distribute their products. Manufacturers should monitor the quality of their products and equipment, ensure relevant marketing activities to increase sales, improve their existing product range and develop new, exclusive products that could occupy a free niche in the market, look for ways to export, diversify or find new ways to market their products in Ukraine.

\section{References}

1. Volkov, V. P. (2010). Otsinka rivnia monopolizmu v kondyterskii haluzi Ukrainy. Visnyk Zaporizkoho natsionalnoho universytetu. $\quad$ Retrieved July $21, \quad 2021, \quad$ from https://web.znu.edu.ua/herald/issues/2010/eco_2010_4/2010_4/181-188.pdf

2. Zahrychanska, A. V., \& Holiuk, V. Ya. (2021). Analiz suchasnoho kondyterskoho rynku Ukrainy. Aktualni problemy ekonomiky ta upravlinnia, (15), 21-26.

3. Derzhavna sluzhba statystyky Ukrainy: Statystychnyi zbirnyk "Vytraty i resursy domohospodarstv Ukrainy". (2019). Retrieved July 29, from http://www.ukrstat.gov.ua/druk/publicat/kat_u/2020/zb/06/zb_vrd_19_ue.pdf

4. Derzhavna sluzhba statystyky Ukrainy: Kilkist sub’iektiv velykoho, serednoho, maloho ta mikropidpryiemnytstva za vydamy ekonomichnoi diialnosti (2010-2019). (2019). Retrieved July 29, 2021, from http://www.ukrstat.gov.ua/

5. Halushko, O. S. (2009). Tendentsii rozvytku rynku kondyterskykh vyrobiv ta osoblyvosti transformatsii u systemi tsinnostei yoho uchasnykiv. Aktualni problemy ekonomiky, (1), 18-19.

6. List of supplying markets for the product imported by Ukraine in 2020. Product: 18 Cocoa and cocoa preparations. Trade Map. (2020). Retrieved August 01, 2021, from https://www.trademap.org/Country_SelProductCountry.aspx?nvpm=5\%7c804\%7c\%7c\%7c\%7c18\%7c\%7c\%7c2\%7c1 $\% 7 \mathrm{c} 1 \% 7 \mathrm{c} 1 \% 7 \mathrm{c} 1 \% 7 \mathrm{c} 1 \% 7 \mathrm{c} 2 \% 7 \mathrm{c} 1 \% 7 \mathrm{c} 1 \% 7 \mathrm{c} 1$

7. Derzhavna sluzhba statystyky Ukrainy: Kilkist sub’iektiv velykoho, serednoho, maloho ta mikropidpryiemnytstva (2010-2019). (2019). Retrieved August 01, 2021, from http://www.ukrstat.gov.ua/

8. Candy Industry's Global Top 100 Candy Companies Lists. (2021). Retrieved August 02, 2021, from https://www.candyindustry.com/Global-Top-100-Candy-Companies 
9. List of importing markets for the product exported by Ukraine in 2020. Product: 17 Sugars and sugar confectionery. Trade Map. (2020). Retrieved August 02, 2021, from https://www.trademap.org/Country_SelProductCountry.aspx?nvpm=1\%7c804\%7c\%7c\%7c\%7c17\%7c\%7c\%7c2\%7c1 $\% 7 \mathrm{c} 1 \% 7 \mathrm{c} 2 \% 7 \mathrm{c} 1 \% 7 \mathrm{c} 1 \% 7 \mathrm{c} 2 \% 7 \mathrm{c} 1 \% 7 \mathrm{c} 1 \% 7 \mathrm{c} 1$

10. Tychynska, A. I., \& Naumova, M. A. (2017). Doslidzhennia rynku kondyterskykh vyrobiv Ukrainy. Visnyk studentskoho naukovoho tovarystva DonNU imeni Vasylia Stusa. Retrieved August 02, 2021, from http://jvestnik-sss.donnu.edu.ua/article/download/4859/4889

11. Rezultaty narodnoho holosuvannia 2020 roku v katehorii «Kondyterski vyroby / Shokolad u plyttsi». Favor.com.ua. (2020). Retrieved August 02, 2021, from https://favor.com.ua/ru/vote/products/chokolatebar/?results $=2020$

12. Dontsul, A., \& Odnolko, V. (2018). Analiz rynku kondyterskykh vyrobiv Ukrainy: problemy ta perspektyvy rozvytku. Naukovyi visnyk Odeskoho natsionalnoho ekonomichnoho universytetu, (5(257)), 67-84.

13. Shashyna, M. V., \& Mrochko, I. I. (2014). Analiz rynku kondyterskoi produktsii v Ukraini: problemy ta perspektyvy rozvytku. Suchasni problemy ekonomiky ta pidpryiemnytstvo, (13), 65-72.

14. Rybak, M. O. Stan ta perspektyvy rozvytku kondyterskoi haluzi v Ukraini. Retrieved August 02, 2021, from https://conf.ztu.edu.ua/wp-content/uploads/2017/12/238.pdf

15. Demianenko, K. A. (2016). Tendentsii rozvytku kondyterskoho rynku Ukrainy v suchasnykh umovakh. Molodyi vchenyi, (9), 45-50.

16. Tobolin, O. O. Analiz ryinka konditerskih izdeliy Ukrainyi: tendentsii. KOLORO - dizayn upakovki i etiketki, sozdanie brenda, pozitsionirovanie, brending. (2018). Retrieved August 02, 2021, from https://koloro.ua/blog/brending-i-marketing/analiz-rynka-konditerskikh-izdeliy-ukrainy-tendentsii.html

Received 10 August 2021

Approved 24 August 2021

Available in Internet 24.10.2021

\section{Самофратова B.A.}

доктор економічних наук, професор

кафедра економіки промисловості

E-mail: vica_samofatova@meta.ua

ORCID ID: 0000-0002-9058-4382

Бова Т.Ю.

магістрант

кафредра економіки промисловості

Одеська національна академія харчових технологій

вул. Канатна, 112, м. Одеса, Україна, 65039

E-mail: tatiana.bova00@gmail.com

ORCID: 0000-0001-9713-3624

\section{ПРОБЛЕМИ ТА ПЕРСПЕКТИВИ РОЗВИТКУ ПІДПРИЄМСТВ КОНДИТЕРСЬКОЇ ПРОМИСЛОВОСТІ В УКРАЇНІ}

Стаття присвячена аналізу сучасного кондитерського ринку України. Досліджено стан кондитерської галузі та виокремлено основні тенденції та проблеми розвитку кондитерського ринку України.

У роботі зазначається, що кондитерська промисловість займає важливе місце у забезпеченні продовольчої безпеки держави. Розвиток кондитерської галузі допомагає забезпечувати населення необхідними обсягами кондитерської продукції, створює попит на продукцію інших галузей, використовуючи на виробництві солодощів вітчизняну сільськогосподарську сировину, сприяє розв'язанню проблем зайнятості населення та збільшенню доходів до державного бюджету.

Визначено, що українського ринок кондитерських виробів на сьогодняшній день знаходиться на етапі завершення свого формування та, несумнівно, в стані жорсткої конкурентної протидії, оскільки серед вподобань вітчизняних споживачів більше 95\% ринку займають товари вітчизняних компаній, число яких з кожних роком невпинно росте.

В роботі визначені основні фрактори, що впливають на підвищення конкурентоспроможності кондитерських підприємств та зумовлюють розвиток кондитерської промисловості в Україні. 
Висвітлено проблеми, пов'язані із забезпеченням виробництва вітчизняною та імпортною сировиною. Вказано перелік найбільших країн-експортерів какао, какао-бобів та какао-продуктів до України.

Розглянуто можливості та проблеми експорту української кондитерської продукції, вказано перелік найбільших країн-імпортерів українських кондитерских виробів. Проаналізовано динаміку співвідношення обсягів експортованої продукції та загального обсягу реалізації кондитерської продукції за кілька років і встановлено основні причини зменшення обсягів експорту кондитерської продукції.

Зазначено шляхи підвищення ефективності реалізації вітчизняної кондитерської продукції. Пояснюється роль маркетингової політики компанії у впливі на вибір споживача. Наведено рейтинг торгівельних марок українських виробників шоколаду в плитках за результатами опитувань споживачів. Розглядаються проблеми збуту кондитерської продукції, пов'язані з обмеженістю торгових площ, невеликою кількістю великих торгівельних мереж та некомпетентністю контрагентів. Запропоновані альтернативні шляхи реалізації кондитерських виробів.

Визначено, що для зміцення своїх позицій на ринку підприємствам взагалом необхідно слідкувати за підтриманням якості своєї продукції та обладнання, забезпечувати актуальність маркетингових заходів задля підвищення об'ємів реалізації продукції, удосконалювати вже існуючий асортимент та розробляти нові, ексклюзивні продукти, які могли б зайняти вільну нішу на ринку, шукати шляхи для експорту, диверсифікації або знаходження нових способів збуту продукції в Україні.

Ключові слова: Кондитерська промисловість, ефективність, конкурентоспроможність, ринки кондитерської промисловості, ринки збуту, експорт, імпорт.

\section{Література}

1. Волков В.П. Оцінка рівня монополізму в кондитерській галузі України // Вісник Запорізького національного $\quad$ університету: $\quad$ [Веб-сайт]. $2010 . \quad$ URL https://web.znu.edu.ua/herald/issues/2010/eco_2010_4/2010_4/181-188.pdf (дата звернення: 21.07.2021).

2. Загричанська А. В., Голюк В. Я. Аналіз сучасного кондитерського ринку України // Актуальні проблеми економіки та управління. 2021. №15(2021). С. 21-26

3. Державна служба статистики України: Статистичний збірник "Витрати і ресурси домогосподарств України": [Веб-сайт]. 2019. URL: http://www.ukrstat.gov.ua/druk/publicat/kat_u/2020/zb/06/zb_vrd_19_ue.pdf (дата звернення: 29.07.2021).

4. Державна служба статистики України: Кількість суб'єктів великого, середнього, малого та мікропідприємництва за видами економічної діяльності (2010-2019): [Веб-сайт]. $2019 . \quad$ URL: http://www.ukrstat.gov.ua/ (дата звернення: 29.07.2021).

5. Галушко О.С. Тенденції розвитку ринку кондитерських виробів та особливості трансформацій у системі цінностей його учасників // Актуальні проблеми економіки. 2009. №1. С. 18-19.

6. TradeMap: List of supplying markets for the product imported by Ukraine in 2020. Product: 18 Cocoa and $\begin{array}{llll}\text { cocoa } & \text { preparations: } & \text { [Веб-сайт]. } & \text { URL: }\end{array}$ https://www.trademap.org/Country_SelProductCountry.aspx?nvpm=5\%7c804\%7c\%7c\%7c\%7c18\%7c\%7c\%7c2\%7c1 \%7c1\%7c1\%7c1\%7c1\%7c2\%7c1\%7c1\%7c1 (дата звернення: 01.08.2021).

7. Державна служба статистики України: Кількість суб'єктів великого, середнього, малого та мікропідприємництва (2010-2019): [Веб-сайт]. 2019. URL: http://www.ukrstat.gov.ua/ (дата звернення: 01.08.2021).

8. Candy Industry's Global Top 100 Candy Companies Lists: [Веб-сайт]. 2021. URL: https://www.candyindustry.com/Global-Top-100-Candy-Companies (дата звернення: 02.08.2021).

9. TradeMap: List of importing markets for the product exported by Ukraine in 2020. Product: 17 Sugars and $\begin{array}{llll}\text { sugar } & \text { confectionery: } & \text { [Веб-сайт]. }\end{array}$ https://www.trademap.org/Country_SelProductCountry.aspx?nvpm=1\%7c804\%7c\%7c\%7c\%7c17\%7c\%7c\%7c2\%7c1 \%7c1\%7c2\%7c1\%7c1\%7c2\%7c1\%7c1\%7c1 (дата звернення: 02.08.2021).

10. Тичинська А. І., Наумова М. А. Дослідження ринку кондитерських виробів України. Вісник студентського наукового товариства ДонНУ імені Василя Стуса: [Веб-сайт]. 2017. URL: http://jvestniksss.donnu.edu.ua/article/download/4859/4889 (дата звернення: 02.08.2021).

11. Результати народного голосування 2020 року в категорії «Кондитерські вироби / Шоколад у плитці» // Favor.com.ua: [Веб-сайт]. 2020. URL: https://favor.com.ua/ru/vote/products/chokolate-bar/?results=2020 (дата звернення: 02.08.2021).

12. Донцул А., Однолько В. Аналіз ринку кондитерських виробів України: проблеми та перспективи розвитку // Науковий вісник Одеського національного економічного університету: зб. наук. праць / Одеський національний економічний університет. 2018. № 5(257). С. 67-84 
13. Шашина М.В., Мрочко I.I. Аналіз ринку кондитерської продукції в Україні: проблеми та перспективи розвитку // Сучасні проблеми економіки та підприємництво. 2014. №13. С. 65-72

14. Рибак M.O. Стан та перспективи розвитку кондитерської галузі в Україні. URL: https://conf.ztu.edu.ua/wp-content/uploads/2017/12/238.pdf (дата звернення: 02.08.2021).

15. Демяненко К.А. Тенденції розвитку кондитерського ринку України в сучасних умовах // Молодий вчений. 2016. №9. С. 45-50

16. Тоболин О.О. Анализ рынка кондитерских изделий Украины: тенденции / KOLORO - дизайн упаковки и этикетки, создание бренда, позиционирование, брендинг. URL: https://koloro.ua/blog/brending-imarketing/analiz-rynka-konditerskikh-izdeliy-ukrainy-tendentsii.html (дата звернення: 02.08.2021).

Стаття надійшла 10.08 .2021 Стаття прийнята до друку 24.08.2021 Доступно в мережі Internet 24.10.2021

Цитування згідно ДСТУ 8302:2015

Samofatova V., Bova T. Problems and prospects of development of confectionery industry enterprises in Ukraine // Food Industry Economics. 2021. Vol.13, Issue 3. P. 56-63. doi: 10.15673/fie.v13i3.2132

Cite as APA style citation

Samofatova,V., \& Bova, T. (2021). Problems and prospects of development of confectionery industry enterprises in Ukraine. Food Industry Economics, 13(2), 56-63. doi: 10.15673/fie.v13i3.2132 